\title{
Effect of methionine compounds on rumen activity of cows
}

\author{
J. Huisman' ${ }^{1}$, E. J. van Weerden ${ }^{1}$, P. van Leeuwen ${ }^{1}$ and F. Koch ${ }^{2}$ \\ ${ }^{1}$ Institute of Animal Nutrition and Physiology (ILOB) TNO, P.O. Box 15, NL \\ 6700 AA Wageningen, Netherlands \\ ${ }^{2}$ Degussa AG, Industrial and Fine Chemicals Division, D-6450 Hanau, Federal \\ Republic of Germany
}

Received 14 April 1986; accepted 27 October 1987

Key words: methionine, methionine compounds, rumen, cattle

\begin{abstract}
In an experiment with two adult rumen-cannulated cows the effect of a liquid methionine preparation (LIQUIMETH) and a protected methionine preparation (MEPRON) on the intensity of the degradation processes in the rumen and on the contents of volatile fatty acids in the rumen fluid was studied. The intensity of the degradation processes was studied by determining the degradation of hay in the rumen with the nylon bag method.

The degradation of dry matter, organic matter and crude protein of hay in the nylon bags was higher during oral administration of methionine. Contents of volatile fatty acids in the rumen fluid were not affected by oral administration of methionine.
\end{abstract}

\section{Introduction}

Methionine is considered as an important amino acid in ruminant nutrition and has been suggested to be the most limiting amino acid for milk protein synthesis (Hatfield \& Richardson, 1978; Spires et al., 1975; Schwab et al., 1976). A positive effect of the supplementation of methionine or methionine hydroxy analog (MHA) to the feed on milk, milk fat and milk protein yield and on fat and protein content in milk has been reported by Bhargava et al. (1977), Chandler et al. (1976), Griel et al. (1968), Holter et al. (1972), Kaufmann \& Lupping (1979), Patton et al. (1970), Polan et al. (1970), Remond et al. (1971), Rosser et al. (1971), Van Hellemond \& Sprietsma (1977), Van Horn et al. (1975).

In other experiments, Hutjens \& Schulz (1971), Stokes et al. (1981), Olson \& Grubauch (1974), Wallenius \& Whitchurch (1975) and Whiting et al. (1972) found that the supplementation of methionine was not effective for the criteria mentioned.

There are various hypotheses to explain the positive effect of methionine on milk 
parameters. A hypothesis can be that the positive effect is related to an increased rumen activity. This hypothesis is based on the finding that during administration of MHA the number of protozoa in the rumen was increased (De Vuyst et al., 1975).

The aim of our study was to investigate the effect of a liquid methionine preparation (Dl-methionine-Na, LIQUIMETH) and a protected methionine preparation (MEPRON) on the intensity of the degradation processes in the rumen and the contents of volatile fatty àcids in the rumen fluid. The intensity of the degradation processes was studied by determining the degradation of hay in the rumen with the nylon bag method.

\section{Materials and methods}

\section{Animals, diets and methionine compounds}

The experiment was carried out with two adult rumen-fistulated cows of the DutchFrisian Black and White breed, yielding approximately $17 \mathrm{~kg}$ milk daily. The cows were fed ad libitum hay, and twice daily (at 8:00 h and 17:00 h) $4.5 \mathrm{~kg}$ pelleted concentrate. The composition of the concentrate is given in Table 1 . The hay contained approximately $11.7 \%$ crude protein.

Two methionine compounds were involved:

- LIQUIMETH* ${ }^{*}$, liquid Dl-methionine-Na, containing approximately $40 \%$ methionine;

- MEPRON*, N-hydroxymethyl Dl-methionine-Ca, containing approximately $68 \%$ methionine.

Table 1. Composition of the concentrate $(\%)$.

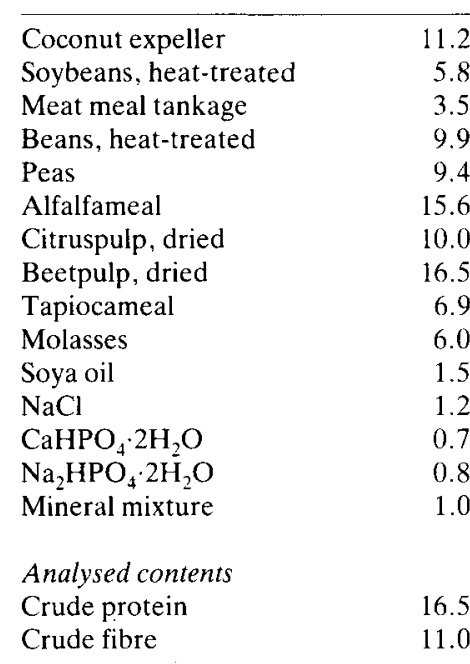

\footnotetext{
* Registered trade marks of Degussa.
} 
To each cow $31 \mathrm{~g}$ LIQUIMETH or $18.5 \mathrm{~g}$ MEPRON corresponding to $12.5 \mathrm{~g}$ methionine was administered twice daily together with the concentrate. At each feeding time, $1 \mathrm{~kg}$ of the pelleted concentrate was mixed with some water and the methionine compound, and fed together with the other part of the concentrate. There were no refusals of concentrate and methionine compounds.

The experiment was carried out according to the following scheme:

\begin{tabular}{|c|c|c|}
\hline Test period & Treatment & Duration \\
\hline- & $\begin{array}{l}\text { Adaptation to feeding the basal diet } \\
\text { (concentrate }+ \text { hay) }\end{array}$ & 56 days before the start of the experiment \\
\hline P1 & $\begin{array}{l}\text { Feeding basal diet without administration } \\
\text { of methionine compounds }\end{array}$ & 16 days after the start of the experiment \\
\hline P2 & $\begin{array}{l}\text { Feeding basal diet }+ \text { oral administration } \\
\text { of LIQUIMETH }\end{array}$ & 18 days after start $P 2$ \\
\hline $\mathrm{P} 3$ & $\begin{array}{l}\text { Feeding basal diet + oral administration } \\
\text { of MEPRON }\end{array}$ & 16 days after start $P 3$ \\
\hline P4 & $\begin{array}{l}\text { Feeding basal diet without administration } \\
\text { of methionine compounds }\end{array}$ & 16 days after start $P 4$ \\
\hline
\end{tabular}

\section{Nylon bag incubations}

The nylon bag incubations were based on the method described by Mehrez \& Orskov (1977). Nylon bags (size $17 \times 9 \mathrm{~cm}$, pore size $41 \mathrm{~nm}$ ) were manufactured at the institute and filled with $5 \mathrm{~g}$ of hay. The hay $(88.2 \%$ dry matter, $7.05 \%$ ash and $11.7 \%$ crude protein) was from one large thoroughly mixed homogeneous $5-\mathrm{kg}$ sample, originating from the large batch fed to the animals. Before being introduced in the bags, the hay was chopped at maximal $5 \mathrm{~mm}$.

The nylon bag incubation protocol started on day 8 of P1, day 13 of P2 and day 11 of $\mathrm{P} 3$ and P4. The filled bags were soaked in water for 1 minute and divided in 3 groups of 16 bags each. One group was not incubated, one group was incubated in the rumen for 24 hours and one group was incubated for 48 hours. Per cow, 16 bags were connected with a piece of lead packed in plastic and placed at the bottom of the rumen. After 24 hours, 8 bags were removed from the rumen; the remaining 8 bags were removed after 48 hours. During incubation it was checked twice daily, whether the bags were still below the surface of the rumen contents. This incubation procedure was repeated on days 3 to 5 of the nylon bag incubation protocol.

After soaking (group I) or after soaking + incubation (group II and group III) the bags were washed for 24 hours in running tap water. The bags were then dried to constant weight and the contents of 8 bags pooled for further chemical analysis. This resulted in 4 individual values for 0,24 and 48 hours of rumen incubation, respectively. Disappearance from the bags was calculated for dry matter, organic matter and nitrogen. An estimate of the disappearance of cell walls was calculated from the disappearance of organic matter minus Nx6.25. 


\section{Sampling of rumen fluid}

In each period, samples of the rumen fluid for VFA-analysis were taken at the same days as the bags were incubated. Samples were taken at $0,2,4,6$ and 8 hours after morning feeding. The rumen fluid was ultrafiltrated immediately after sampling and the supernatant was preserved with toluene $(0.4 \mathrm{ml}$ per $100 \mathrm{ml}$ supernatant $)$. The supernatants of the five days were pooled per sampling time. So, for each cow a pooled sample at $0,2,4,6$ and 8 hours after morning feeding was obtained. The samples were analysed for acetic acid, propionic acid and total volatile fatty acids.

\section{Results and discussion}

The amounts of dry matter and $\mathrm{N}$ washed out of the bags of group I, (not incubated in the rumen) ranged between $12.7 \%$ and $15.8 \%$ for dry matter and between $15.0 \%$ and $25.1 \%$ for $\mathrm{N}$ (Table 2). These figures are used for correction of the results of the groups II and III, incubated in the rumen for 24 and 48 hours, respectively. For example the disappearance of dry matter in P1 (control) after 24 hours incubation followed by washing was $45.4 \%$; corrected for the disappearance after only washing, the disappearance was $45.7-13.9=31.8 \%$.

The results for the degradation of dry matter, organic matter and crude protein and cellwall material are presented in Table 3. Comparing the figures of 24 and $48 \mathrm{~h}$ incubation time, they nearly show the same course: a significant increase in crude protein degradation and a significant but lower increase in the degradation of dry and organic matter and cell wall material during oral administration of LIQUIMETH (P2) and MEPRON (P3) as compared to the first control period (P1), in which no methionine was administered. The results of $\mathrm{P} 2$ and $\mathrm{P} 3$ are only compared with the first control period P1, because in the second control period (P4) the degradation was almost the same as in the test periods P2 and P3, in which methionine was administered. Most likely, this is an indication that the time between the periods $\mathrm{P} 3$ and $\mathrm{P} 4$ was too short. An explanation might be that the increase in growth of micro-organisms (P1, P2) starts earlier than a decrease as a result of starvation due to shortage of methionine.

During administration of LIQUIMETH the disappearance of crude protein was on average about 15.7 percentage units (mean of $24 \mathrm{~h}$ and $48 \mathrm{~h}$ ) higher than in the former control period P1. The disappearance of organic matter exceeds the control

Table 2. Disappearance (\%) of dry matter and $\mathrm{N}$ after washing only (group I, not incubated in the rumen).

\begin{tabular}{lll} 
& Dry matter & $\mathrm{N}$ \\
$\mathrm{P} 1$ & 13.9 & 17.4 \\
$\mathrm{P} 2$ & 12.7 & 15.0 \\
$\mathrm{P} 3$ & 14.4 & 18.3 \\
$\mathrm{P} 4$ & 15.8 & 25.1 \\
\hline
\end{tabular}


Table 3. Degradation of dry matter, organic matter, cell wall material and crude protein from hay in nylon bags incubated in the rumen of cows. Percentage disappeared after incubation and washing. (Figures found after correcting for the percentage disappeared after washing only).

\begin{tabular}{|c|c|c|c|c|c|c|c|}
\hline Test & Dry & & Org & ratter & Cell & naterial $^{1}$ & Crude protein \\
\hline & abs. & SE & abs. & SE & abs. & SE & \\
\hline
\end{tabular}

Percentage disappeared after $24 \mathrm{~h}$

$\begin{array}{lllllllll}\text { P1, control } & 31.8^{\mathrm{a} 2} & 1.9 & 33.1^{\mathrm{a}} & 2.0 & 32.4^{\mathrm{a}} & 2.0 & 37.0^{\mathrm{a}} & 2.3 \\ \text { P2, LIQUIMETH } & 36.6^{\mathrm{b}} & 1.8 & 38.1^{\mathrm{b}} & 1.8 & 35.2^{\mathrm{b}} & 2.0 & 54.6^{\mathrm{c}} & 1.5 \\ \text { P3, MEPRON } & 37.3^{\mathrm{b}} & 1.8 & 38.7^{\mathrm{b}} & 1.9 & 37.3^{\mathrm{bc}} & 2.0 & 47.2^{\mathrm{b}} & 1.6 \\ \text { P4, control } & 36.8^{\mathrm{b}} & 1.7 & 38.8^{\mathrm{b}} & 1.9 & 37.9^{\mathrm{c}} & 1.9 & 44.4^{\mathrm{b}} & 1.6\end{array}$

Percentage disappeared after $48 \mathrm{~h}$

\begin{tabular}{lllllllll} 
P1, control & $47.8^{\mathrm{a}}$ & 2.0 & $49.8^{\mathrm{a}}$ & 2.1 & $49.0^{\mathrm{a}}$ & 2.3 & $54.3^{\mathrm{a}}$ & 1.6 \\
P2, LIQUIMETH & $52.2^{\mathrm{b}}$ & 1.2 & $54.5^{\mathrm{b}}$ & 1.2 & $52.1^{\mathrm{b}}$ & 1.2 & $68.1^{\mathrm{c}}$ & 2.4 \\
P3, MEPRON & $52.9^{\mathrm{b}}$ & 1.1 & $55.0^{\mathrm{h}}$ & 1.1 & $54.0^{\mathrm{b}}$ & 1.2 & $60.7^{\mathrm{b}}$ & 0.7 \\
P4, control & $51.8^{\mathrm{b}}$ & 0.8 & $54.4^{\mathrm{b}}$ & 0.9 & $54.0^{\mathrm{b}}$ & 1.0 & $56.8^{\mathrm{a}}$ & 0.5 \\
\hline
\end{tabular}

${ }_{1}$ Calculated from organic matter minus crude protein ( $\mathrm{Nx6.25)}$.

${ }^{2}$ Figures not having the same superscript in the column differ significantly $(P<0.05)$.

period $\mathrm{P} 1$ on average by 4.8 percentage units, for cell wall material the effect was in average 3.0 units. This means that from each kg hay an extra amount of $811.5 \mathrm{~g} \times$ $4.8 \%=39.4 \mathrm{~g}$ organic matter disappeared, of which $117 \mathrm{~g} \times 15.7 \%=18.4 \mathrm{~g}$ was crude protein and $704.5 \times 3.0 \%=21.1 \mathrm{~g}$ cell wall material. These results indicate that the effect of LIQUIMETH on degradation was, in relative terms, more related to protein than to other organic matter components. After the change from LIQUIMETH to MEPRON the protein degradation (mean of $24 \mathrm{~h}$ and $48 \mathrm{~h}$ ) decreases signigicantly from about $61 \%$ to about $54 \%$ (Table 2). But the degradation during administration of MEPRON was still significantly higher compared to control period P1.

The degradation of organic matter was more constant and did not differ between the period P2 (LIQUIMETH) and P3 (MEPRON). The results suggest that the activity of ruminal micro-organisms was increased by oral administration of methionine. In in vitro studies by Gil et al., (1973), Guardiola et al. (1983), Salsbury et al. (1971) and Spears et al. (1976) indications have been found that methionine or MHA stimulated the digestibility of cellulose and carbohydrates. Patton et al. (1970) and De Vuyst et al. (1975), found a considerable increase in total number of protozoa in the rumen during administration of MHA.

Summarizing the results of the present experiment and those reported in literature, one can speculate that the increased degradation of hay in the nylon bags is a result of increased degradation capacity caused by an increased number of microorganisms.

The mean contents of acetic acid, propionic acid and total fatty acids in the rumen 


\section{CONTENTS}

(MG/100 ML)

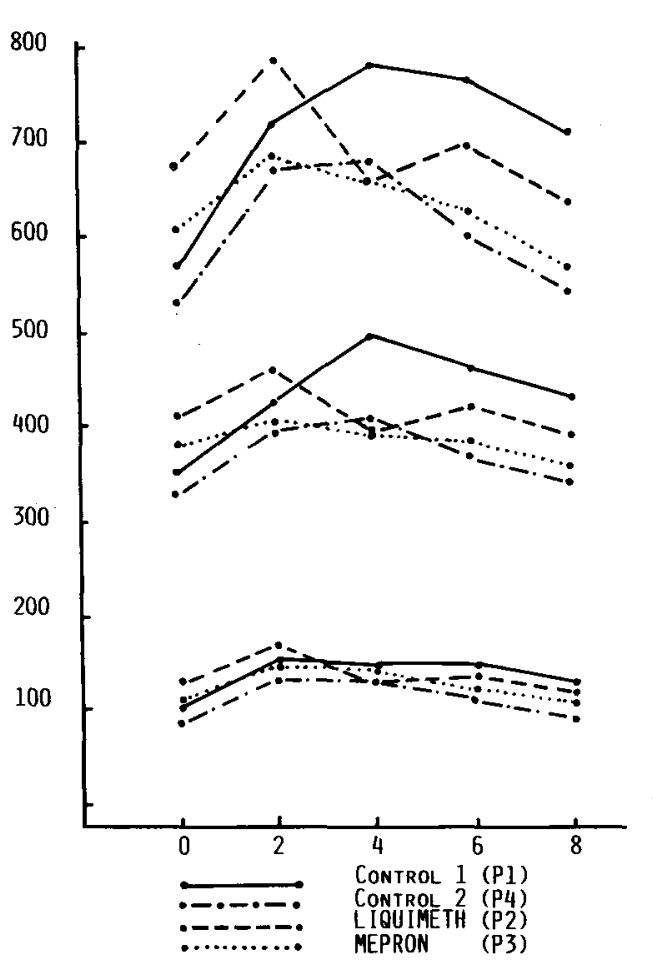

TOTAL ACIDS

ACETIC ACID

PROPIONIC ACID

TIME AFTER FEEDING(h)

Fig. 1. Mean contents of volatile fatty acids in rumen fluid.

fluid are given in Fig. 1. Oral administration of LIQUIMETH or MEPRON showed no distinct effect on the contents of volatile fatty acids in the rumen fluid. There is a tendency that the contents slightly decreased during the course of the experiment. This study does not allow a calculation of changes in rumen outflow or absorption rate of volatile fatty acids from the rumen.

\section{References}

Bhargava, P. K., D. E. Otterby, J. M. Murphy \& J. D. Donker, 1977. Methionine hydroxy analog in diets for lactating cows. Journal of Dairy Science 60: 1594-1604.

Chandler, P. T., C. A. Brown, R. P. Johnston Jr., G. K. MacLeod, R. D. McCarthy, B. R. Moss, A. H. Rakes \& L. D. Satter, 1976. Protein and methionine hydroxy analog for lactating cows. Journal of Dairy Science 59: 1897-1909.

De Vuyst, A., M. Van Belle, J. M. Joassart \& A. Baquette, 1975. The effect of MHA-supplementation of the diet and concentration of ciliate protozoa in the rumen of sheep. Zeitschrift für Tierphysiologie, Tierernährung und Futtermiddelkunde 35: 316-321. 


\section{EFFECT OF METHIONINE ON RUMEN ACTIVITY OF COWS}

Gil, L. A., R. L. Shirley \& J. E. Moore, 1973. Effect of methionine hydroxy analogue on growth, amino acid content and catabolic products of glucolytic rumen bacteria in vitro. Journal of Dairy Science 56: $757-762$.

Griel. L. C., R. A. Patton, R. D. McCarthy \& P. T. Chandler, 1968. Milk production response to feeding methionine hydroxy analogue to lactating dairy cows. Journal of Dairy Science 51: 1866-1868.

Guardiola, C. M. G. C. Fahey, J. W. Spears, U. S. Garrigus, O. A. Isquierdo \& C. Pedroza, 1983. The effects of sulfur supplementation on cellulose digestion in vitro and on nutrient digestion, nitrogen metabolism and rumen characteristics of lambs fed on good-quality fescue and tropical stargrass hays. Animal Feed Science and Technology 8: 129-138.

Hatfield, E. E. \& C. R. Richardson, 1978. The limiting amino acids in growing cattle. Journal of Animal Science 46: 740-745.

Holter, J. B., C. W. Kim \& N. F. Colovos, 1972. Methionine hydroxy analogue for lactating dairy cows. Journal of Dairy Science 55: 460-465.

Hutjens, M. F. \& L. H. Schultz, 1971. Addition of soybeans or methionine analog to high-concentrate rations for dairy cows. Journal of Dairy Science 54: 1637-1644.

Kaufmann, W. \& W. Lupping., 1979. Zum Einfluss von Protected Protein und HHM-Ca auf die Leistung von Milchkühen. Zeitschrift für Tierphysiologie, Tierernährung und Futtermittelkunde 41: 202217.

Mehrez, A. Z. \& E. R. Orskov, 1977. A study of the artificial fibre bag technique for determining the digestibility of feeds in the rumen. Journal of Agricultural Science (Cambridge) 88: 645-650.

Olson, H. H. \& W. R. Grubach, 1974. Effect of methionine hydroxy analog feeding on yield and composition of bovine milk. Journal of Dairy Science 57: 695-697.

Patton, R. A., R. D. McCarthy \& L. C. Griel, 1970. Observations on rumen fluid, blood serum and milk lipids of cows fed methionine hydroxy analogue. Journal of Dairy Science 53: 776-780.

Polan, C. E., P. T.. Chandler \& C. N. Miller, 1970. Methionine hydroxy analogue: Varying levels for lactating cows. Journal of Dairy Science 53: 607-610.

Remond, B., C. Champredon, D. Decaen, R. Pion \& M. Journet, 1971. Influence d'un apport de D1Méthionine à de vache au debut de la lactation sur la production laitière et la composition du sang. Annales de Biologie Animale Biochimie Biophysique 11: 455-469.

Rosser, R. A., C. E. Polan, P. T. Chandler \& T. L. Bibb, 1971. Effects of whey components and methionine analog on bovine milk fat production. Journal of Dairy Science 54: 1807-1816.

Salsbury, R. L., D. K. Marvil, C. W. Woodmansee \& G. F. W. Haenlein, 1971. Utilization of methionine and methionine hydroxy analog by rumen micro-organisms in vitro. Journal of Dairy Science 54: 390-396.

Schwab, C. G., L. D. Satter \& A. B. Clay, 1976. Response of lactating dairy cows to abomasal infusion of amino acids. Journal of Dairy Science, 59: 1254-1270.

Spears, J. W., D. G. Ely, L. P. Bush \& R. C. Buckner, 1976. Sulfur supplementation and in vitro digestion of forage cellulose by rumen organisms. Journal of Animal Science 43: 513-517.

Spires, H. R., J. H. Clark, R. G. Derrig \& C. L. Davis, 1975. Milk production and nitrogen utilization in response to postruminal infusion of sodium caseinate in lactating cows. Journal of Nutrition 105: 11111121.

Stokes, M. R., J. H. Clark \& L. Steinmetz, 1981. Performance of lactating dairy cows fed methionine or methionine analogue at two concentrations of dietary crude protein. Journal of Dairy Science 64: 1686-1694.

Van Hellemond, K. K. \& J. E. Sprietsma, 1977. Effect of supplementation of methionine and methionine hydroxy analogue on milk yield, milk fat and milk protein. Zeitschrift für Tierphysiologie, Tierernährung und Futtermittelkunde 39: 109-115.

Van Horn, H. H., S. P. Marshall, C. J. Wilcox, P. F. Randel \& J. M. Wing, 1975. Complete rations for dairy cattle. III. Evaluation of protein percent and quality and citrus pulp-corn substitutions. Journal of Dairy Science 58: 1101-1108.

Wallenius, R. W. \& R. E. Whitchurch, 1975. Methionine hydroxy analog of sulfate supplementation for high-producing dairy cows. Journal of Dairy Science 58: 1314-1319.

Whiting, F. M., J. W. Stull, W. H. Brown \& B. L. Reid, 1972. Free amino acid ratios in rumen fluid, blood plasma, milk and feces during methionine and methionine hydroxy analog supplementary feeding. Journal of Dairy Science 55: 983-988. 